\title{
RELATIONSHIPS BETWEEN TECHNICALLY-ORIENTED SECONDARY SCHOOL COURSES AND A COLLEGE PRIVATE PILOT GROUND SCHOOL
}

\author{
Hope Bouvette Thornberg, Ph.D. \\ Robert W. Isaacson, M.A. \\ with the assistance of \\ Patrick Mattson, M.S. \\ St. Cloud State University
}

\begin{abstract}
This study was undertaken to determine if there is a relationship between final grades received in secondary school technically-oriented courses and the final grade received in a college private pilot ground school course. Ninety-six first-year students enrolled in the ground school course comprised the sample, with data for 51 aviation pre-major students and 45 non-aviation pre-major students examined both as two separate samples and as a single sample. Final grades earned by these students in secondary school elementary algebra, geometry and advanced algebra, the mean of the three mathematics final grades, the mean of the secondary science final grades and the mean of the secondary English final grades were used as independent variables. The final grades earned in Technology 101, Private Pilot Ground School, were used as the dependent variable.
\end{abstract}

From the analysis, it may be concluded that, when grades earned by aviation pre-major students and non-aviation pre-major students were analyzed as one sample, there was a relationship for all students between the private pilot ground school course and all of the secondary school technically-related courses. When the grades earned by aviation pre-majors were analyzed alone, there were relationships between only the ground school course and geometry and the mean of the final grades earned in secondary mathematics courses. The analysis of the grades earned by non-aviation pre-majors revealed relationships between the ground school course and all of the secondary school technically-related courses. There was no relationship between the ground school course and the mean of the final grades earned in secondary English courses for any of the three samples studied.

This study suggests that secondary school mathematics plays a role in preparing all students for a college private pilot ground school course. Secondary school geometry appears to play a particularly significant role in preparing pre-aviation majors who are taking a private pilot ground school course as an initial professional course.

\section{Introduction}

Collegiate aviation educators often are asked by secondary school counselors and teachers for recommendations regarding secondary school courses which provide the best preparation for college aviation courses, particularly pilot ground schools and other technically-oriented aviation courses. Collegiate aviation faculty frequently recommend that secondary school courses having a similar orientation, i.e., mathematics and science, provide the best preparation for technically-oriented college aviation courses. While a relationship has not been established between these secondary 
school technically-oriented courses and college technically-oriented aviation courses, it might be theorized that, based upon similar orientation, such a relationship could exist.

Gimmestad (1989) reported that a relationship exists between a college engineering design course and secondary school mathematics, student spatial visualization skills and a combination of drafting, shop and solid geometry courses. Of these three variables, spatial visualization is the most significant, mathematics is second and drafting, shop and solid geometry third. She suggests that students who are weak in these skills will be less likely to succeed in a college engineering design course than students who are strong in these areas.

Oman (1986) found mathematics proficiency to be correlated with successful completion of college computer science courses. Marsh and Anderson (1985) reported that achievement on a Biomathematics Skills Pre-test as well as secondary school grade point average were found to be predictors of success in a college introductory biology course.

This study had three general purposes:

\section{Purpose of the Study}

1. To determine if there is a relationship between secondary school technically-related courses, i.e., mathematics and science, and a college private pilot ground school course.

2. To determine if there is a relationship between secondary school non-technically related courses, i.e., English courses, and a college private pilot ground school course.

3. To determine if relationships between secondary school technically related courses and a college private pilot ground school course and secondary school non-technically related courses and a college private pilot ground school course differ between those students planning to major in aviation and taking the college course as the initial professional course and those not planning this major and taking the course as general education.

\section{Methodology}

The samples used in the study were 51 first-year pre-aviation major students (Group A), 45 first-year students who were not pre-aviation majors (Group B) and Group A and Group B students combined $(\mathrm{N}=96)$ for whom secondary school academic records were available. The students were enrolled in seven sections of Technology 101, Private Pilot Ground School, taught during fall and winter quarters, 1990-91, at St. Cloud State University. The curriculum for this course has been approved by the Federal Aviation Administration under Federal Aviation Regulations, Part 141. The sections were taught by three different instructors, all using this curriculum, the same text, work books, visual aids and the same four unit examinations and final examination.

The final grades earned by Group A and Group B students in Technology 101 were used as the dependent variable for each group in this study. These data were collected from instructor end-of-quarter grade reports for fall and winter quarters, 1990-91.

Quantitative data were collected from Group A and Group B student secondary school academic records. The final grades earned by the students in elementary algebra, geometry and advanced algebra were 
used as independent variables for each group in this study. Secondary school final letter grades were converted to numbers with $A=4, B=3, C=2$ and $D=1$.

While not all students in the two groups had taken all three secondary mathematics courses, all had taken at least two and the mean of the final grades earned in these courses was used as an independent variable. The least number of students in either group enrolled in any one of the three mathematics courses was 36 , with the majority of students having taken all three courses. The mean of the final grades earned by the students in secondary science courses was used as an independent variable as was the mean of the final grades earned by the students in secondary English courses. In Group A, 50 of 51 students had taken at least two science courses and two English courses. In Group B, all 45 students had taken at least two science courses and two English courses.

\section{Analysis of Data}

The null hypothesis that each of the independent variables $(x)$ was unrelated to the dependent variable $(y)$ was tested using a $T$-test and a confidence interval of 95 percent was constructed. A simple regression equation was derived for each of the relationships. From this data, correlation ( $r$ ) was used to examine the extent to which each of the independent variables, the final grades earned in secondary elementary algebra, geometry and advanced algebra courses, the mean of final mathematics grades, the mean of final science grades and the mean of final English grades, were related to the dependent variable, final grades earned in Technology 101, Private Pilot Ground School.

The analysis of the six independent variables of all students (Group A and Group B) and the dependent variable, Technology 101, of all students revealed that the null hypothesis can be rejected in the relationship between the final grades earned in Technology 101 and the final grades earned in elementary algebra, geometry, advanced algebra, the mean of the final grades earned in the three mathematics courses and the mean of the final grades earned in secondary science courses. The null hypothesis cannot be rejected in the relationship between Technology 101 and the mean of the final grades earned in secondary English courses. Refer to Table 1.

The analysis of the six independent variables of Group $A$ and the dependent variable of Group $A$ revealed that the null hypothesis can be rejected in the relationship between the final grades earned in Technology 101 and the final grades earned in geometry and the mean of the final grades earned in the three mathematics courses. Refer to Table 2.

The null hypothesis cannot be rejected for Group $A$ in the relationship between the final grades earned in Technology 101 and the final grades earned in elementary algebra, advanced algebra, the mean of the final grades earned in secondary science courses and the mean of the final grades earned in secondary English courses. Refer to Table 2.

The analysis of the six independent variables of Group B and the dependent variable of Group B revealed that the null hypothesis can be rejected in the relationship between the final grades earned in Technology 101 and the final grades earned in elementary algebra, geometry, advanced algebra, the mean of the final grades earned in secondary mathematics courses and the mean of the final grades earned in secondary science courses. The null hypothesis cannot be rejected in the relationship between final grades earned in Technology 101 and the mean of the final grades earned in secondary English courses. Refer to Table 3 . 
Table 1

\begin{tabular}{|l|l|l|l|}
\hline Independent & Dependent & Correlation( $)$ & Null \\
\hline Variables & Variable & All Students & $\mathrm{B}=0$ \\
\hline Elem Algebra & TECH 101 & 0.23 & $0.0210484<\mathrm{B}<0.4274236$ \\
\hline Geometry & TECH 101 & $0.1711000<\mathrm{B}<0.5869000$ \\
\hline Adv Algebra & TECH 101 & 0.28 & $0.0590633<\mathrm{B}<0.4619577$ \\
\hline Math Mean & TECH 101 & $0.1736482<\mathrm{B}<0.5673118$ \\
\hline Science Mean & TECH 101 & 0.35 & $0.0968825<\mathrm{B}<0.6083995$ \\
\hline English Mean & TECH 101 & 0.16 & $0.0428354<\mathrm{B}<0.4673234$ \\
\hline
\end{tabular}

Table 2

\begin{tabular}{|c|c|c|c|}
\hline Independent & Dependent & Correlation(r) & Null Hypothesis \\
\hline Variables & Variable & Group A & $B=0$ \\
\hline Elem Algebra & TECH 101 & 0.22 & $-0.0669070<\mathrm{B}<0.4646300$ \\
\hline Geometry & TECH 101 & 0.41 & $0.1402174<B<0.6581080$ \\
\hline Adv Algebra & TECH 101 & 0.28 & $-0.0144477<B<0.4972939$ \\
\hline Math Mean & TECH 101 & 0.36 & $0.0955700<\mathrm{B}<0.6304500$ \\
\hline Science Mean & TECH 101 & 0.21 & $-0.0829830<B<0.6010970$ \\
\hline English Mean & TECH 101 & 0.19 & $-0.1041820<B<0.5515500$ \\
\hline
\end{tabular}

Table 3

\begin{tabular}{|l|l|l|l|}
\hline Independent & Dependent & Correlation( $\mathbf{r}$ ) & Null Hypothesis \\
\hline Variables & Variable & $\mathrm{B}=0$ \\
\hline Elem Algebra & TECH 101 & $0.0218779<\mathrm{B}<0.5988101$ \\
\hline Geometry & TECH 101 & 0.33 & $0.2718060<\mathrm{B}<0.3430444$ \\
\hline Adv Algebra & TECH 101 & $0.0390967<\mathrm{B}<0.6750533$ \\
\hline Math Mean & TECH 101 & $0.1389460<\mathrm{B}<0.7139940$ \\
\hline Science Mean & TECH 101 & 0.41 & $0.0982990<\mathrm{B}<0.8499750$ \\
\hline English Mean & TECH 101 & 0.36 & $0.1395580<\mathrm{B}<0.6612100$ \\
\hline
\end{tabular}

From this analysis, one may conclude that, when grades earned by aviation pre-major students (Group A) and non-aviation pre-major students (Group B) are analyzed as one sample, there is a relationship for all students between the dependent variable, Technology 101, and five of the six independent variables. Refer to Table 1.

One also may conclude that there is a relationship for Group A between the dependent variable and two of the six independent variables: geometry and secondary mathematics courses. The relatively high correlation $(r=0.41)$ for the relationship between geometry and Technology 101 may indicate that the regression equation may have some value as a predictor of success in a private pilot ground school course for aviation pre-majors who are prepared in secondary school geometry. While this analysis does not suggest that relationships exist between Technology 101 and elementary algebra or advanced 
algebra, there is a relationship between Technology 101 and the mean of final grades earned in secondary mathematics courses. Refer to Table 1 . Further, relationships are present between the dependent variable and both elementary algebra and advanced algebra in the analysis of data for all students. Refer to Table 1.

It may be concluded further from this analysis that there is a relationship for Group B between the dependent variable and five of the six independent variables: elementary algebra, geometry, advanced algebra, secondary school mathematics courses and secondary school science courses. However, none of the correlations for the relationships between Technology 101 and the three mathematics courses is as high for this group as is the correlation for the relationship between Technology 101 and geometry for Group A. The relatively high correlation $(r=0.41)$ for the relationship between Technology 101 and the mean of final grades earned in secondary school mathematics may indicate that the regression equation may have some value as a predictor of success in a private pilot ground school course for non-aviation pre-majors who are prepared in secondary mathematics.

An independent $t$-test was conducted to determine whether there was a statistically significant difference between the mean scores for Group A students, aviation pre-majors, and Group B students, non-aviation pre-majors, in TECH 101, Private Pilot Ground School. There was no significant difference between the mean score for Group $\mathrm{A}(\mathrm{Ya}=2.4)$ and Group $\mathrm{B}(\mathrm{Yb}=2.1)$.

\section{Conclusion}

This study suggests that secondary school mathematics plays a role in preparing all students for a college private pilot ground school course. Secondary school geometry appears to play a particularly significant role in preparing pre-aviation majors who are taking a private pilot ground school course as an initial professional course. It further suggests that secondary school science courses play a role in preparing students for a college private pilot ground school course, non-aviation pre-major students to a greater extent than aviation pre-major students. While English courses do not appear to play a role in preparing students for a technically-oriented course such as private pilot ground school, it must be emphasized that representatives of the aviation industry have indicated that the ability to communicate verbally and in writing is essential for success in all facets of the industry.

The study also suggests that achievement in geometry may be useful in predicting success in a college private pilot ground school course for those students taking this course as an initial professional aviation course. It further suggests that overall achievement in mathematics may be useful in predicting success in a college private pilot ground school course for those students taking this course for general education. Further research should include multiple regression analysis to rank the significance of each of the independent variables examined in this study in relation to the dependent variable, a private pilot ground school course, and to determine if relationships exist among these independent variables. 


\section{References}

Gimmestad, Beverly J., Gender differences in spatial visualization and predictors of success in an engineering design course. Proceedings of The National Conference on Women in Mathematics and the Sciences November, 1989, St. Cloud, MN.

Marsh, Jeffrey and Anderson, Norman, An assessment of the quantitative skills of students taking introductory college biology courses. Proceedings of the Annual Meeting of the National Association for Research in Science Teaching, April, 1985, French Lick Springs, IN.

Oman, Paul W., ldentifying student characteristics influencing success in introductory computer science courses. Association for Educational Data Systems Journal Vol. 19 pp. 226-33, 1986. 